\title{
Demographic and Psychosocial Determinants of Life Satisfaction Among Youths in Nigeria: Evidence from the Multiple Indicators Cluster Survey
}

\author{
V. Chima \\ Department of Demography \& Social Statistics, Obafemi Awolowo University, \\ Ile-Ife, Osun State, Nigeria \\ O. A. Alawode (Corresponding author) \\ Department of Demography \& Social Statistics, Obafemi Awolowo University, Ile-Ife, \\ Osun State, Nigeria \\ E-mail: alawode1990@gmail.com
}

\begin{abstract}
A. F. Awoleye
Department of Demography \& Social Statistics, Obafemi Awolowo University, Ile-Ife,

Osun State, Nigeria

O. Hawa

Bill \& Joyce Cummings Institute of Global Health,

University of Global Health Equity, Rwanda

\section{I. Chima}

Centre for Gender and Social Policy Studies, Obafemi Awolowo University, Ile-Ife,

Osun State, Nigeria;

Reastat Development Initiative (RDI), Nigeria
\end{abstract}

Received: April 6, 2020 Accepted: August 1, 2020 Published: September 18, 2020

doi:10.5296/ijssr.v8i2.16802 URL: http://dx.doi.org/10.5296/ijssr.v8i2.16802 


\begin{abstract}
Subjective Wellbeing, implying an evaluation of one's life has recently received intellectual attention, especially in developed countries. Measuring this concept entails both an effective and cognitive evaluation of life. Life satisfaction plays a vital role in positive life outcomes as a key part of the cognitive component of subjective wellbeing. Various factors could determine the current state of wellbeing on an individual. Leveraging on one of the surveys that collect data on subjective wellbeing in Nigeria, we examined the determinants of life satisfaction among youths in Nigeria, with a concentration on the demographic and psychosocial factors. Multiple Indicator Cluster Survey (MICS) data for Nigeria $(n=18,454)$ was analyzed using chi-square tests and binomial logistic regression in Stata 14. The result showed that gender, residence, and region significantly determined life satisfaction. For psychosocial factors influencing life satisfaction; health, family life satisfaction, friendship, treatment by others, and perceived improvement in comparison to last year, significantly determine life satisfaction. Specifically, male resident in rural areas of Nigeria were more likely to report satisfaction with life. Further, youths that reported satisfaction with family life were more likely to be satisfied with life in general, while satisfaction with health, friendships, treatment by others, and improved condition from last year influenced satisfaction with life. In conclusion, it has been shown that beyond the socio-demographic factors, psychosocial determinants play vital roles in determining life satisfaction among youths. It is therefore imperative that government agencies consider policies and interventions that address psychosocial support for youths in Nigeria.
\end{abstract}

Keywords: socio-demographic, psychosocial, life satisfaction, youths, Nigeria, subjective wellbeing, Multiple Indicator Cluster Survey (MICS) 


\section{Introduction}

In the last three decades, subjective wellbeing which captures an individual's subjective evaluation of their lives has experienced increased attention among scholars worldwide. Different components of wellbeing have been identified and distinguished by scholars, with (Steptoe, Deaton, \& Stone, 2015) identifying three components which include; evaluative wellbeing (or life satisfaction), hedonic wellbeing (feelings of happiness, sadness, anger, stress, and pain), and eudemonic wellbeing (sense of purpose and meaning in life) while (Diener \& Diener, 1993) divided wellbeing into two components which include cognitive (life satisfaction) and affective (positive and negative effect). According to Pavot and Diener (2008); Ozmete (2011), and the Organization for Economic Cooperation and Development OECD's (2013) guidelines, measuring the concept of subjective wellbeing entails both an effective and cognitive evaluation of life. Therefore, it is an aspect of the quality of life or subjective well-being of individuals that is based on life experiences and events (Dyrdal et al., 2011; Hlavac, 2011; Steger \& Kashdan, 2007). The effective evaluation examines the measurement of anger, worry, or happiness while cognitive evaluation assesses income, work, or health (Thieme \& Dittrich, 2015). Life satisfaction, the focus of this study has been defined as a cognitive component of subjective wellbeing and plays an important role in positive life outcomes among individuals. Also, it is the evaluative or cognitive component of subjective wellbeing dependent on the information-based assessment of an individual's life for which people judge the extent to which their life so far measures up to their expectations. It also bears a resemblance to their envisioned 'ideal' life, whereas the affective part is a hedonistic estimation guided by emotions and feelings.

There have been various definitions for the components of subjective wellbeing especially life satisfaction. Prominently, Neugarten et al. (1961) stated that life satisfaction is an operational definition of successful aging. It is a positive evaluation of one's conditions of life at some point in life. A judgment that at least on the balance measures up favorably against standards and expectations set by individuals for themself. In addition, Maddox (1987) in the encyclopedia of Aging defines life satisfaction as a subordinate construct of subjective wellbeing, others being happiness, mood, and morale. Other definitions of life satisfaction have been based on several factors including; happiness (Ibem \& Amole, 2013; Berry \& Okulicz-Kozaryn, 2009; Dyrdal et al., 2011; Ozmete, 2011; Veenhoven, 1996), good life (Peterson, Park, \& Seligman, 2005) standard of living and quality of life (Fadda \& Jiron, 1999; Ibrahim \& Chung, 2003; Yuan, 2001).

Life satisfaction is regarded as an aggregate satisfaction with life in its different domains (Ibem \& Amole, 2013; Van Praag \& Ferreri Carbonell, 2003) of family life, employment, social activities, recreation, health, consumption, ownership of properties, self, and spiritual life (Day, 1987); marriage, the standard of living, friendship, sex life, and leisure (Headey \& Wearing, 1992); material well-being, productivity, intimacy, safety, community and emotional well-being (Cummins, 1996) as well as money, social relationships, education and housing (Argyle, 2001).

In conclusion, life satisfaction portrays an overall assessment of feelings and attitudes about 
one's life at a point in time ranging from negative to positive. Hence, it agrees with the cognitive theory of an individual's cognitive judgment about comparisons based on the compatibility of their living conditions with the standards (Diener, Emmons, Larsen, \& Griffen, 1985). It is an assessment of the overall conditions of existence as derived from a comparison of one's aspiration to one's actual achievement. Research points to the fact individuals attach different meanings to life outcomes thereby making life satisfaction a personal or individual decision depending on each person's value orientation (Suh et al., 1998).

\subsection{Determinants of Life Satisfaction}

Numerous studies have examined determinants of life satisfaction and there have been mixed results on the impact of socio-demographic, economic, and other factors. Van Praag et al. (2003) found that individual domain satisfactions depend on objectively measurable variables particularly individual income and earnings, with health and income found to be key determinants of life satisfaction in the study. Individual demographics including age and sex have also been found to impact life satisfaction as revealed in (Ferring et al., 2004) where age had a significant influence on life satisfaction, especially among females in comparison to males. Calasanti (2008); Muzamil Jan and Tasia Masood (2008); Saundra and Hughey (2003); Kousha and Moheen (2004) and Khanna Shipra (2015) have all in their studies reported that the overall life satisfaction decreases with age among women and with increasing personal or family income satisfaction among women, life satisfaction improves. In addition, Subasi and Hayran (2005) and Delhey (2004) reported that neither age nor gender positively affected life satisfaction. In similar studies, Pavot and Diener (1993) and Dyrdal et al. (2011) found that demographics (marital status) significantly predicted life satisfaction in the study population. For Suh et al. (1998) personal emotions and norms are predictors of life satisfaction in individualist and collectivist cultures, respectively. In the same vein, economic status, culture (Bailey \& Snyder, 2007; Diener, Gohm, Suh, \& Oishi, 2000; Tucker et al., 2006), and mental health (Pavot \& Diener, 2008) have all been identified as determinants of life satisfaction.

In Banjare et al. (2015), it was stated that according to WHO; there are four factors directly influencing life satisfaction and these include physical health, mental health, social relationship and, environment with a specific focus on the aged. Peterson et al. (2004) found that among youths, mental health and good adaptation were predictors of satisfaction with life while psychological, social, and behavioral problems necessitated dissatisfaction with life. Also, a moderate effect of socioeconomic status specifically income and educational level were associated with life satisfaction, while age and gender played limited roles as found by (Suh et al., 2012; Ra et al., 2013). Psychosocial factors such as social support, positive social relations, physical and psychosocial wellbeing played significant roles in the determination of life satisfaction (Keyes, Shmotkin, \& Ryff, 2002). Numerous works of literature have revealed that wellbeing and life satisfaction has overtime been evaluated based on objective and subjective parameters (Becchetti, Castriota, \& Solferino, 2011; Yuan, 2001). While satisfaction has been examined with life scale which examines the objective parameters of access to basic necessities of life such as food and medical care (Peterson et al., 2005; Tucker, Ozer, Lyubomirsky, \& Boehm, 2006; Steger \& Kashdan, 2007), the subjective parameters are 
based on individual's own set criteria (Ozmete, 2011).

Finally, with increased attention on subjective wellbeing, the majority of the studies conducted have been in developed and industrialized nations with the results mostly generalized to developing countries and this universalist perspective fails to recognize that determinants of wellbeing may have different importance for people across different countries, which might also lead to different policy implications. Further, developing countries especially sub-Sahara Africa lags on detailed research on wellbeing and life satisfaction with most studies in the region concentrated on the elderly or the general population, few have considered examining life satisfaction among youths aged 15-24. Therefore, this study examined the determinants of life satisfaction among youths in Nigeria, with specific consideration on the demographic and psychosocial factors influencing life satisfaction.

\subsection{Life Satisfaction Models and Theories}

Several models and theories have been used to explain life satisfaction. Neal et al. (1999) constructed a model based on the assumption that "life satisfaction is functionally related to satisfaction with all of life's domains and subdomains". In 2004, Neal and Sirgy (2004) further validated this model by showing a correlation between satisfaction with leisure life and satisfaction with life in general. Similarly, Sirgy, Rahtz, Cicic, and Underwood (2000) developed a similar model and included leisure as part of the "global satisfaction with other life domains" (Sirgy \& Comwell, 2001; Sirgy et al., 2000). In addition, Charles (2002) using a longitudinal framework and national representative sample to better understand the relationship between job satisfaction and life satisfaction over time, examined a job and life satisfaction model that included both environmental conditions and personality measures. In the model, satisfaction with Life Index was created by calculating subjective well-being based on health, wealth, and access to basic education (Dolan et al., 2007).

Other theories of great relevance to the study of Subjective Wellbeing (Life Satisfaction) includes the Affective theory, Expectancy theory, Goal-setting theory, and the Attribution theory. Each of these theories opined that life satisfaction is an individual's conscious experience as to the dominance of their positive emotions over their negative emotions. In other words, a positive mood is related to motivation across a wide range of situations (Wright \& Staw, 1999).

Another relevant hypothesis is the spillover hypothesis which opines a positive correlation among domains and concludes that domains influence each other and life satisfaction altogether, with reciprocal influences. This means a decrease in work satisfaction can be offset by an increase in other life satisfaction domains such as satisfaction with health, friendships, comparison with life in the previous year, which is also strongly positively correlated to overall life satisfaction (Sirgy, Mentzer, Rahtz, \& Meadow, 1991). Results from various studies have supported this hypothesis as observed by McAdams, Lucas, and Donnellan (2012) using the British household panel survey data which showed that domain satisfactions may have different trajectories than overall life satisfaction, and declines in some areas such as health can be offset by increases in other areas such as income, work, 
social life or amount of leisure time. The effect of intervening variables shows that cultural and economic conditions of the environment such as financial satisfaction correlates more strongly in poorer settings (Diener \& Diener, 1993). Also, moderator variables have been discussed, such as personal importance of domains (disaggregation hypothesis, see Rice et al., 1992) but also cultural and economic conditions of the environment, e.g., financial satisfaction correlates more strongly with life satisfaction in poorer countries (Diener \& Diener, 1993). According to a meta-analysis by Cummins (1996), the most relevant life domains contributing to life satisfaction are economic condition, family circumstances, health, and work. Argyle (2001) analyzed domains such as money, health, job and employment, social relationships, leisure, housing, and education.

\section{Methods}

This section describes the study procedures of how the data was derived and extracted from the data set, as well as the statistical technique used for the study.

\subsection{Data and Sample}

Data for this study was extracted from the fifth round of Multiple Indicator Cluster Survey (MICS5) which was conducted in 2016/2017 by the National Bureau of Statistics (NBS) together with the National Primary Health Care Development Agency (NPHCDA) and National Agency for the Control of Aids (NACA). Appropriate ethical approval was sought from the national ethical committee. The sample for the 2016/2017 MICS5 was a multistage stratified sampling approach, the stratification was done by dividing the country into geo-political zones from which states were identified. Afterward, Enumeration Areas (EAs) were selected while the final stage was the selection of households within the selected EAs. A total of 2,239 EAs were covered out of 2,340. A representative sample of 37,440 households was interviewed. The sample weight was calculated and added to the data file to adjust for the non-proportional allocation of the sample. Women and men aged 15-49 were interviewed for the survey. The inclusion criteria for this were women and men within aged 15-24. Informed consent was obtained from respondents by asking respondents whether to commence the interview after the interviewer provided greetings and detailed introduction and information about the survey. The weighted sample size analyzed was 18,454 men and women who were age 15-24 years. The men and women datasets were merged using the cluster number, household number, and line numbers as primary keys.

\subsection{Dependent Variable}

The dependent variable used for this study was life satisfaction and it was recoded into two categories: satisfied and unsatisfied. That is $1=$ satisfied and $0=$ unsatisfied.

\subsection{Independent Variables}

Socio-demographic characteristics of respondents were selected as follows: Wealth index, level of education, geopolitical zone, age of respondents, place of residence, and sex. To determine the psychosocial satisfaction of eligible respondents, they were asked whether they were satisfied with health, family, friendship, treatment by others, and appearance. Those 


\section{Macrothink}

variables were used in this study as determinants of psychosocial factors as it was captured in the survey questionnaire. Both socio-demographic and psychosocial factors were used as independent variables.

\subsection{Statistical Analysis}

Three levels of analyses were carried out for the study namely: univariate, bivariate, and multivariate using Stata version 14 software. Frequency, percentage distribution, and graphs were used at the univariate level of the analysis to present each socio-demographic characteristics and psychosocial variables. Chi-square test was employed at the bivariate level to test for the level of association between explanatory variables and the response variable at a 95\% confidence interval. Finally, binary logistic regression was used at the multivariate level of analysis to fit an appropriate model for the study. Variables having significant associations with the dependent variables were fitted into the binary logistic regression model, with two models developed. In the first model, the relationship between satisfaction with life and socio-demographic variables that were found to be statistically significant at the bivariate level was explored and the second model determined the relationship between satisfaction with life, socio-demographic variables, and some intervening variables including satisfaction with income, satisfaction with current job, satisfaction with health and satisfaction with family lifestyle.

\section{Data Analyses and Results}
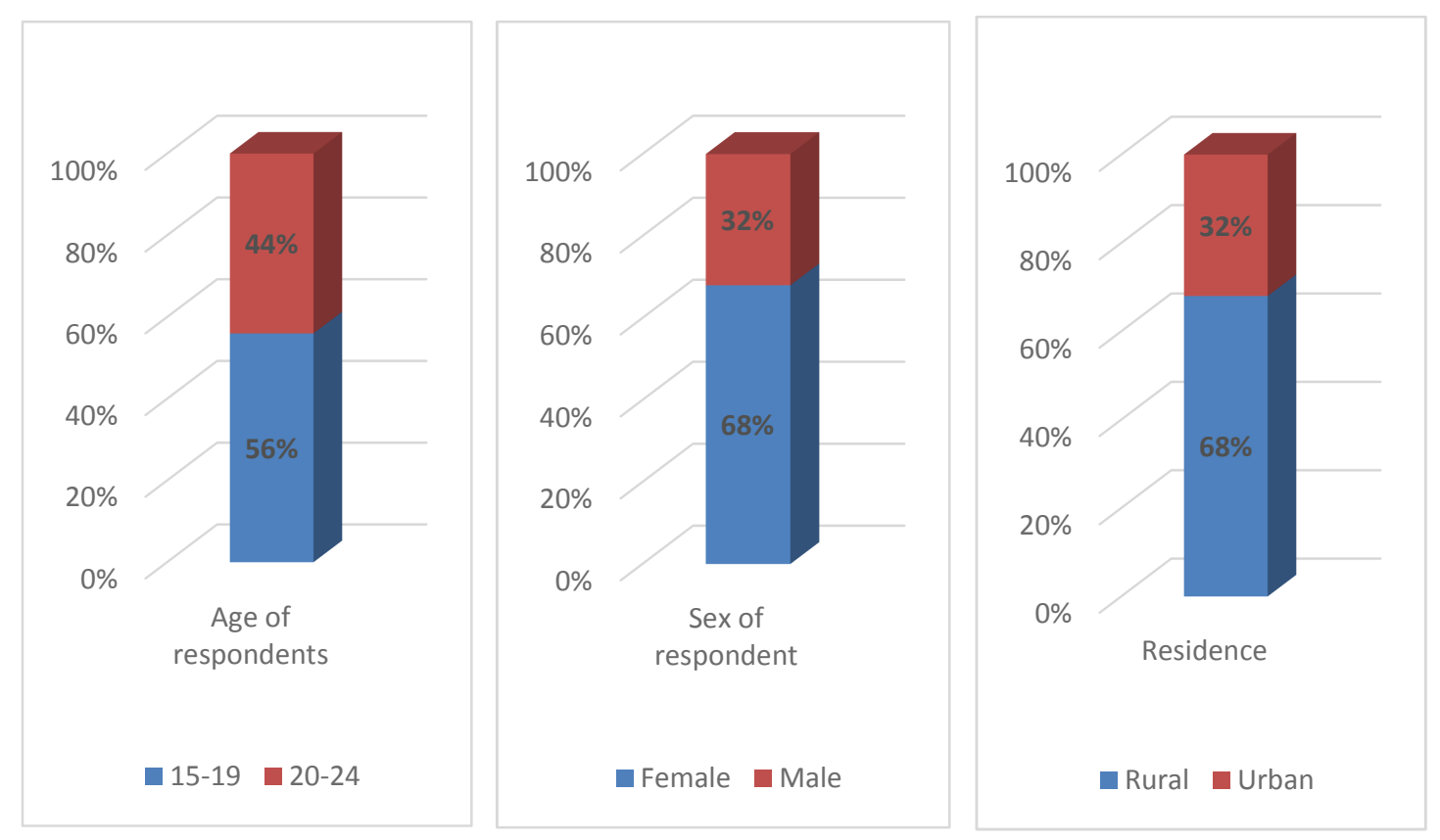

Figure 1. Socio-demographic Variables $(n=18,454)$ 
The chart shows that 56 percent of youths in the study were between ages 15-19 years while others were between $20-24$ years. The mean age of the youths was 18.9 years $(\mathrm{SD}=2.8)$. The proportion of females in the study was 68 percent and 68 percent of respondents were residents in rural areas.

Table 1. Socio-demographic variables of respondents

\begin{tabular}{lll}
\hline Variables & Frequency & Percent \\
\hline Educational Level & & \\
Non-formal & 1967 & 12.37 \\
Primary & 1815 & 11.41 \\
Secondary/technical & 10715 & 67.37 \\
Higher & 1407 & 8.85 \\
Household Wealth Index & & \\
Poorest & 2950 & 16.10 \\
Poorer & 3684 & 20.10 \\
Richer & 3867 & 21.10 \\
Richest & 3870 & 21.12 \\
Geopolitical Zone & & \\
North central & 3827 & 20.88 \\
North east & 2977 & 16.24 \\
North west & 5148 & 28.09 \\
South east & 1932 & 10.54 \\
South south & 2441 & 13.32 \\
South west & 2003 & 10.93 \\
\hline
\end{tabular}

Data revealed that almost 80 percent of the youths had secondary or technical education while 10 percent had higher education and a combined proportion of 10 percent having either non-formal or primary education. Household wealth quintile revealed that middle, richer, and richest wealth categories each had more than 20 percent of youths in those categories, 15 percent were in the poorer category while less than 10 percent of youths were in the poorest category. Only the North central and North west zones had more than 20 percent each of youths while other zones accounted for more than 10 percent but less than 20 percent of youths. 


\section{Macrothink}

International Journal of Social Science Research

ISSN 2327-5510 2020, Vol. 8, No. 2

Table 2. Psychosocial determinants of life satisfaction $(n=18,454)$

\begin{tabular}{lll}
\hline Variables & Frequency & Percent \\
\hline Satisfaction with health & & \\
Unsatisfied & 330 & 2.40 \\
Neither & 578 & 4.21 \\
Satisfied & 12828 & 93.39 \\
Satisfaction with family life & & \\
Unsatisfied & 513 & 3.73 \\
Neither & 923 & 6.71 \\
Satisfied & 12300 & 89.56 \\
Satisfaction with Friendships & & \\
Unsatisfied & 2169 & 11.80 \\
Satisfied & 16211 & 88.20 \\
Satisfaction with Treatment by others & & \\
Unsatisfied & 2489 & 13.54 \\
Satisfied & 15890 & 86.46 \\
Satisfaction with Appearance & & \\
Unsatisfied & 1145 & 6.23 \\
Satisfied & 17233 & 93.77 \\
Comparison with Last year & & \\
Worsen & 1383 & 7.53 \\
Same & 3700 & 20.14 \\
Improved & 13284 & 72.33 \\
Exposure to media & & \\
Daily & 3189 & 23.22 \\
At least once a week & 7532 & 21.94 \\
No exposure & 3012 & \\
\hline
\end{tabular}




\section{Macrothink}

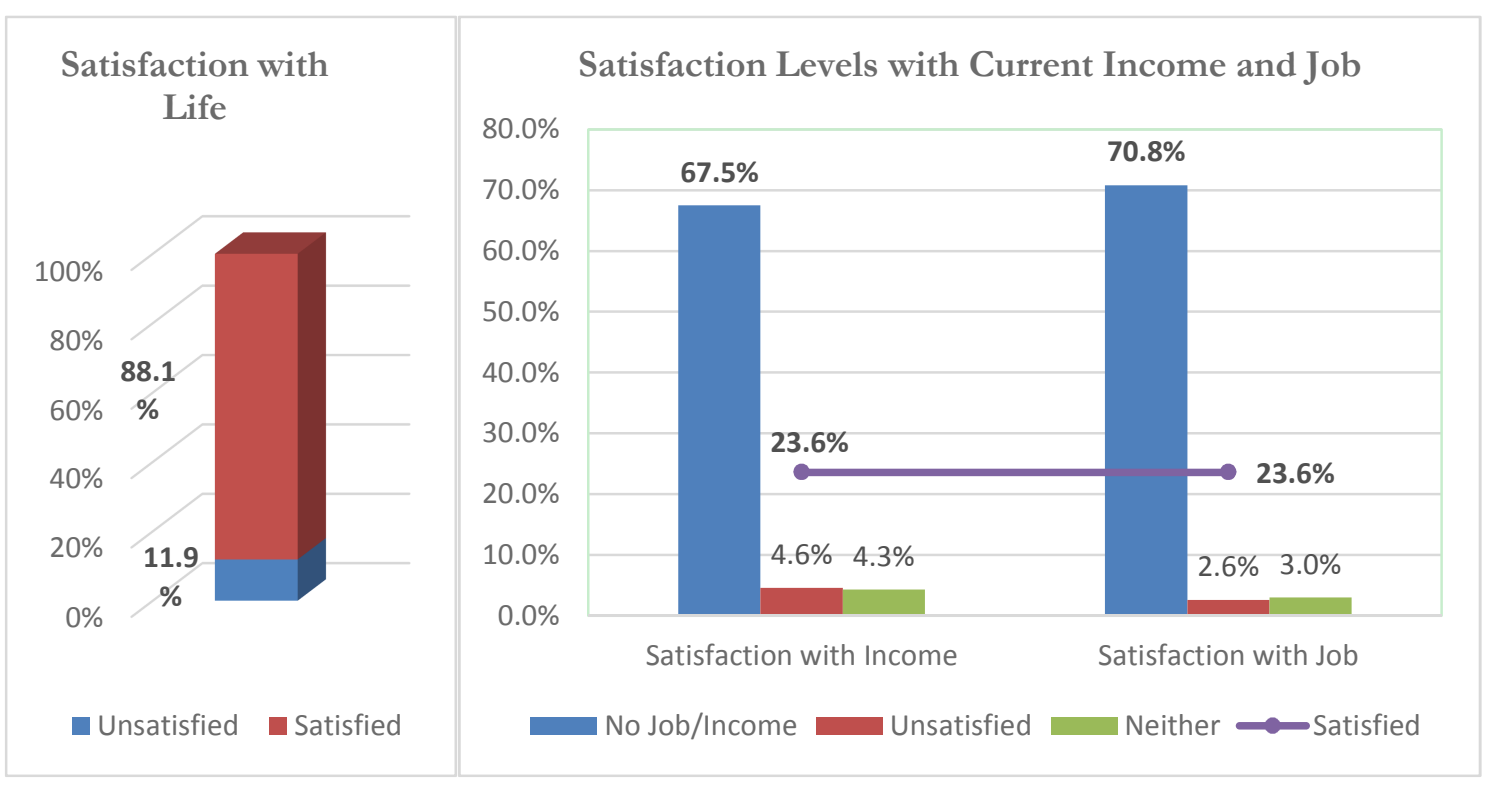

Figure 2. Life satisfaction and socio-demographic variables

Amongst the total number of youths in the study, 88 percent reported satisfaction with life although 71 percent and 68 percent did not have jobs and any source of income respectively. Amongst those that reported having jobs and a source of income, an equal proportion (23\%) reported being satisfied with their jobs and current income. More than 80 percent of youths reported being satisfied with each of health, family life, friendship, treatment by others, and appearance. Also, 72 percent of youths reported improvements in their lives in comparison to last year, 7 percent reported worsened condition while 20 percent remained the same. Access to media at least once a week or daily was reported by 78 percent of youths.

Table 3. Association between socio-demographic characteristics, psychosocial factors, and life satisfaction

\begin{tabular}{|c|c|c|c|}
\hline Variables & & Unsatisfied & Satisfied \\
\hline \multicolumn{4}{|l|}{ Age } \\
\hline $15-19$ & & $862(10.79 \%)$ & $7130(89.21 \%)$ \\
\hline $20-24$ & & $774(13.47 \%)$ & $4970(86.53 \%)$ \\
\hline$\chi^{2}=23.04$ & $\mathrm{p}<0.05$ & & \\
\hline \multicolumn{4}{|l|}{ Sex } \\
\hline Female & & $1144(12.93 \%)$ & 7705 (87.07\%) \\
\hline Male & & $492(10.07 \%)$ & $4395(89.93 \%)$ \\
\hline$\chi^{2}=24.55$ & $\mathrm{p}<0.05$ & & \\
\hline \multicolumn{4}{|c|}{ Level of Education } \\
\hline Non-formal & & $8390(52.19 \%)$ & $7684(47.81 \%)$ \\
\hline Primary & & $166(38.08 \%)$ & $270(61.92 \%)$ \\
\hline
\end{tabular}


Secondary/Technical

Higher

$\chi^{2}=8.54$

$\mathrm{p}<0.05$

Household Wealth Index

Poorest

Poorer

Middle

Richer

Richest

$\chi^{2}=24.63$

$\mathrm{p}<0.05$

Residence

Urban

Rural

$\chi^{2}=8.41$

$\mathrm{p}<0.05$

Region

North Central

North East

North West

South East

South South

South West

$\chi^{2}=53.43$

$\mathrm{p}<0.05$

Exposure to Media

Daily

At least once a week

None

$\chi^{2}=4.00$ $\mathrm{p}>0.05$

Satisfaction with Family Life

Unsatisfied

Neither

Satisfied

$\chi^{2}=100.60$

$\mathrm{p}<0.05$

\section{Satisfaction with Current Income}

No income

Unsatisfied

Neither

Satisfied

$\chi^{2}=552.43$

$\mathrm{p}<0.05$

Satisfaction with Current Job

Unemployed

Unsatisfied

Neither

Satisfied

$412(12.92 \%)$
$1004(10.84 \%)$

$11(34.38 \%)$

$141(10.01)$

$117(11.04 \%)$

$271(13.23 \%)$

$430(13.52 \%)$

434 (11.96\%)

384 (10.05\%)

$599(10.93 \%)$

1037 (12.56\%)

$351(11.75 \%)$

157 (9.65\%)

292 (9.933\%)

307 (16.23\%)

$295(12.50 \%)$

234 (12.13\%)

877 (11.64\%)

347 (11.52\%)

$283(55.17 \%)$

$338(36.62 \%)$

$1015(8.25 \%)$

237 (37.74\%)

$145(24.37 \%)$

$250(7.70 \%)$

$1083(11.13 \%)$
$144(44.72 \%)$
$112(26.79 \%)$
$297(9.17 \%)$

8644 (88.87\%)

208 (55.28\%)

$306(73.21 \%)$

2942 (90.83\%)
$21(65.62 \%)$

$1268(89.99 \%)$

$943(88.96 \%)$

1777 (86.77\%)

$2750(86.48 \%)$

3194 (88.04\%)

3436 (89.95\%)

$4883(89.07 \%)$

7217 (87.44\%)

2637 (88.25\%)

$1470(90.35 \%)$

2648 (90.07\%)

1585 (83.77\%)

2065 (87.50\%)

1695 (87.87\%)

$2779(87.08 \%)$

$6655(88.36 \%)$

2666 (88.48\%)

$230(44.83 \%)$

585 (63.38\%)

$11285(91.75 \%)$

$8262(89.16 \%)$

391 (62.26\%)

$450(75.63 \%)$

2997 (92.30\%) 
$\chi^{2}=399.17 \quad \mathrm{DF}=1 \quad \mathrm{p}<0.05$

Satisfaction with Health

Unsatisfied

Neither

Satisfied

$\chi^{2}=780.64$

$\mathrm{DF}=1 \quad \mathrm{p}<0.05$

Satisfaction with Friendships

Unsatisfied

Satisfied

$784(36.30 \%)$

$1376(67.70 \%)$

$1329(8.22 \%)$

$\chi^{2}=105.03$

$\mathrm{DF}=1 \quad \mathrm{p}<0.05$

Satisfaction with Treatment by others

Unsatisfied

Satisfied

$916(37.00 \%)$

$1197(7.55 \%)$

$\chi^{2}=108.02$

$\mathrm{DF}=1 \quad \mathrm{p}<0.05$

Satisfaction with Appearance

Unsatisfied

$611(53.69 \%)$

$527(46.31 \%)$

Satisfied

$1502(8.74 \%)$

$\chi^{2}=201.30$

$\mathrm{DF}=1 \quad \mathrm{p}<0.05$

Comparison with Last year

Worsen

Same

Improved

$\chi^{2}=970.42 \quad \mathrm{DF}=1 \quad \mathrm{p}<0.05$

Married/Living with a Partner

No

Yes

$1562(11.68 \%)$

$572(11.34 \%)$

$\chi^{2}=2.02 \quad \mathrm{DF}=1 \quad \mathrm{p}>0.05$

Currently Smokes Cigarettes

No

Yes

$344(15.05 \%)$

$71(17.84 \%)$

$\chi^{2}=2.02$

$\mathrm{DF}=1$

$\mathrm{p}>0.05$

\section{Days Drank Last Month}

None

$226(16.45 \%)$

1-10 days

$175(15.28 \%)$

10days and above

$50(13.33 \%)$
$11814(88.32 \%)$

$4470(88.66 \%)$

$1942(84.95 \%)$

$1148(83.55 \%)$

$970(84.72 \%)$

$944(68.46 \%)$

$2989(80.98 \%)$

$12282(92.64 \%)$

$327(82.16 \%)$

$325(86.67 \%)$

Note. $* *$ significant at $\mathrm{p}<0.05$.

$\chi^{2}=2.30 \quad \mathrm{DF}=1 \quad \mathrm{p}>0.05$

Findings from the analysis revealed that the age of respondents, level of education attained, area of residence (rural/urban), the geopolitical zone of residence, wealth index, and gender were the socio-demographic variables associated with life satisfaction. The psychosocial 
variables associated with life satisfaction include satisfaction with; family life, current job, current income, health, friendship, treatment by others, appearance, and perceived improved condition in comparison with the previous year. These variables were associated with life satisfaction at $\mathrm{p}<0.05$.

\section{Multivariate Analysis}

Table 4. Socio-demographic and psychosocial determinants of life satisfaction among youths in Nigeria

\begin{tabular}{|c|c|c|c|c|}
\hline & Model 1 & & Model 2 & \\
\hline Variables & Odds Ratio & CI & Odds Ratio & CI \\
\hline \multicolumn{5}{|l|}{ Age } \\
\hline $15-19$ & 1 & & 1 & \\
\hline $20-24$ & $0.77 * *$ & $0.69-0.85$ & $0.85 * *$ & $0.75-0.96$ \\
\hline \multicolumn{5}{|l|}{ Gender } \\
\hline Female & 1 & & 1 & \\
\hline Male & $1.29 * *$ & $1.16-1.44$ & $1.20 * *$ & $1.05-1.36$ \\
\hline \multicolumn{5}{|l|}{ Educational Level } \\
\hline Non-formal & 1 & & 1 & \\
\hline Primary & $0.59 * *$ & $0.47-0.74$ & $0.71 * *$ & $0.54-0.92$ \\
\hline Secondary/Technical & $0.67 * *$ & $0.55-0.83$ & $0.66 * *$ & $0.53-0.84$ \\
\hline Higher & 0.83 & $0.63-1.09$ & 0.76 & $0.55-1.04$ \\
\hline \multicolumn{5}{|l|}{ Residence } \\
\hline Rural & $1.20 * *$ & $1.03-1.39$ & 0.87 & $0.75-1.01$ \\
\hline \multicolumn{5}{|l|}{ Region } \\
\hline North Central & 1 & & 1 & \\
\hline North East & $1.22 * *$ & $1.02-1.47$ & $1.27 * *$ & $1.02-1.58$ \\
\hline North West & 1.16 & $0.99-1.35$ & 1.04 & $0.86-1.25$ \\
\hline South East & $0.64 * *$ & $0.55-0.77$ & 0.87 & $0.72-1.06$ \\
\hline South South & 0.86 & $0.73-1.02$ & 0.92 & $0.76-1.11$ \\
\hline South West & $0.82 * *$ & $0.68-0.98$ & 0.89 & $0.72-1.10$ \\
\hline \multicolumn{5}{|l|}{ Wealth Index } \\
\hline Poorest & 1 & & 1 & \\
\hline Poorer & 0.96 & $0.49-0.91$ & 0.99 & $0.79-1.24$ \\
\hline Middle & 0.92 & $0.48-0.87$ & 0.92 & $0.73-1.15$ \\
\hline Richer & 1.16 & $0.56-1.03$ & 1.07 & $0.84-1.36$ \\
\hline Richest & $1.38 * *$ & $0.63-1.19$ & 1.14 & $0.87-1.40$ \\
\hline \multicolumn{5}{|c|}{ Satisfaction with current income } \\
\hline No income & & & 1 & \\
\hline Unsatisfied & & & $0.39 * *$ & $0.30-0.51$ \\
\hline Neither & & & $0.46^{* *}$ & $0.36-0.61$ \\
\hline Satisfied & & & 1.15 & $0.94-1.40$ \\
\hline Satisfaction with cur & & & & \\
\hline
\end{tabular}


Unsatisfied

1

Satisfied

Satisfaction with health

Unsatisfied

Neither

Satisfied

Satisfaction with family life

Unsatisfied

Neither

Satisfied

Satisfaction with Friendships

Unsatisfied

Satisfied

Satisfaction with Treatment by

others

Unsatisfied

Satisfied

Comparison of Life with Last Year

Worsen

Same

Improved

Note. ${ }^{* *}$ significant at $\mathrm{p}<0.05$.
0.94

1.04

1.28

0.67-1.31

0.77-1.40

1.05-1.56

1

1.02

0.75-1.39

$2.75 * *$

$2.12-3.56$

1

$1.59 * *$

1.24-2.04

$3.48 * *$

$2.78-4.35$

1

$2.03 * *$

$1.76-2.33$

1

$2.89 * *$

2.54-3.20

1

$1.35 * *$

1.13-1.62

$2.74 * *$

$2.32-3.24$

The multivariate model revealed that amongst the socio-demographic characteristics of youths in Nigeria; gender $(\mathrm{OR}=1.29, \mathrm{CI}=1.16-1.44)$, residence $(\mathrm{OR}=1.20, \mathrm{CI}=$ 1.03-1.39), and region were significantly associated with life satisfaction in model 1. However, the introduction of psychosocial variables in model 2 revealed that only gender of respondents was the socio-demographic characteristic significantly associated with life satisfaction while satisfaction with health $(\mathrm{OR}=2.75, \mathrm{CI}=2.12-3.56)$, family life ( $\mathrm{OR}=$ $3.48, \mathrm{CI}=2.78-4.35)$, friendships $(\mathrm{OR}=2.03, \mathrm{CI}=1.76-2.33)$, treatment by others $(\mathrm{OR}=$ $2.89, \mathrm{CI}=2.54-3.20)$, and perceived improvement in comparison to last year $(\mathrm{OR}=2.74, \mathrm{CI}$ $=2.32-3.24$ ), were significant determinants of life satisfaction. Specifically, male, resident in rural areas of Nigeria were more likely to report satisfaction with life. Further, youths that reported satisfaction with family life were 3 times more likely to be satisfied with life in general, while satisfaction with health, friendships, treatment by others, and improved condition from last year's more than double influenced satisfaction with life.

\section{Discussion and Conclusion}

This study enhances our understanding of life satisfaction among youths with specific emphasis on the socio-demographic and psychosocial determinants of life satisfaction. It lays 
credence to other studies that found specific socio-demographic variables influencing life satisfaction. Specifically, gender influenced life satisfaction among youths, this supports the findings of Bradburn (1969), Diener et al (1985, 2000), Inglehart (1997), Kelly (1993), Krause et al. (1993), MacNeil et al. (1987), Mannell and Dupuis (1996) and Penning and Strain (1994). Although not surprising; age, gender, marital status, education, and income differentiate subjects' life satisfaction. Younger people, men, and married, highly educated, and high-income subjects report higher scores in life satisfaction measures than older people, women, the widowed, divorced, less educated, and low-income earners. These study results are in accordance with those of Bradburn (1969), Diener et al. (1985, 2000), Inglehart (1997), Kelly (1993), Krause et al. (1992), MacNeil and Teague (1987), Mannell and Dupuis (1996) and Penning and Strain (1994). Specifically, the study found that men were significantly more likely to be more satisfied with their lives than women. This finding is in stark contrast to what has been found in a similar study in Australia where it was reported that females were more unusually more satisfied with their own life than males (Cummins, Eckersley, Pallant, Van Vugt, \& Misajon, 2002). Another study also found that both education and income significantly determine life satisfaction. It has been found that both, directly and indirectly, i.e. through interaction with other factors, these two socio-demographic characteristics of people are significant predictors of life satisfaction (Fernandez-Ballesteros, Zamarron, \& Ruiz, 2001). The findings of these studies in Nigeria are that education and household wealth index are significant predictors of life satisfaction. The findings of this present study on the significant relationship between income and life satisfaction also find support in a study in Nigeria where it was reported that income is one of the strongest predictors of subjective life satisfaction among the study population (Ibem \& Amole, 2013).

Furthermore, a study on the predictors of life satisfaction in Serbia found that satisfaction with standard of living and household income robustly predicts life satisfaction among men and women across all age groups (Jovanović \& Joshanloo, 2019). These findings lend credence to the findings of our study as we also found that satisfaction with current income, household wealth index which could be a proxy for standard of living and health all significantly predict life satisfaction among the respondents in the study. Also, a study conducted in Sweden on the relationship between satisfaction with health and life satisfaction found that perceived good health among the respondents was significantly associated with life satisfaction (Melin, Fugl-Meyer, \& Fugl-Meyer, 2003). Also, the same study in Sweden reported that socio-demographic characteristics of the respondents including education, employment, financial situation, gender, and marital status are all significantly associated with perceived life satisfaction among the respondents (Melin et al., 2003). This is supported by what has been found in the present study as it was reported that marital status is a significant predictor of satisfaction with life among the youths. In addition, (Steptoe, Deaton, \& Stone, 2015) found a significant relationship between demographic factors and life satisfaction. Specifically, age, sex, marital status were significant predictors of life satisfaction. This was also found in Nigeria. Finally, a study in Germany found that life satisfaction was reduced with an increase in age (Thieme \& Dittrich, 2015). This is also part of the findings of this study. 
This study has shown the key socio-demographic determinants of life satisfaction among youths in Nigeria. It has also revealed that beyond the socio-demographic factors, psychosocial determinants play vital roles in determining life satisfaction among youths. It is therefore imperative that government agencies consider policies and interventions that address and provides socio-demographic and psychosocial support to youths in Nigeria.

\section{Acknowledgment}

The authors wish to acknowledge the National Bureau of Statistics, Nigeria for the release of the study data and the United Nations Children Fund (UNICEF) who provided technical support for the survey and permitted us to use the data for this paper.

\section{Declaration}

This research did not receive any specific grant from funding agencies in the public, commercial, or not-for-profit sectors.

\section{Conflict of interest}

The authors certify that they have NO affiliations with or involvement in any organization or entity with any financial interest (such as honoraria; educational grants; participation in speakers' bureaus; membership, employment, consultancies, stock ownership, or other equity interest; and expert testimony or patent-licensing arrangements), or non-financial interest (such as personal or professional relationships, affiliations, knowledge or beliefs) in the subject matter or materials discussed in this manuscript.

\section{Data availability}

The dataset of the Multiple Indicator Cluster Survey (MICS) obtained from https://mics.unicef.org/surveys was used for this study.

\section{References}

Argyle, M. (2001). The Psychology of Happiness. London: Routledge, https://doi.org/10.4324/9781315812212

Bailey, T. C., \& Snyder, C. R. (2007). Satisfaction with life and hope: A look at age and marital status. The Psychological Record, 57, 233-240. https://doi.org/10.1007/BF03395574

Banjare, P., Dwivedi, R., \& Pradhan, J. (2015). Factors associated with the life satisfaction amongst the rural elderly in Odisha, India. Health Qual Life Outcomes, 13, 201. https://doi.org/10.1186/s12955-015-0398-y

Becchetti, L., Castriota, S., \& Solferino, N. (2011). Development projects and life satisfaction: An impact study on fair trade handicraft producers. Journal of Happiness Studies, 12, 115138. https://doi.org/10.1007/s10902-009-9179-9

Berry, B. J. L., \& Okulicz-Kozaryn, A. (2009). Dissatisfaction with city life: A new look at some old questions. Cities, 29(3), 17-124. https://doi.org/10.1016/j.cities.2009.01.005

Bradburn, N. M. (1969). The structure of psychological wellbeing. Chicago: Aldine 
publishing.

Calasanti, T. (2008). Theorizing feminist gerontology, sexuality, and beyond: An intersectional approach. In M. Silverstein, V. L. Bengston, N. Putney \& D. Gans (Eds.), Handbook of theories of aging (2nd ed., pp. 471-485). New York, NY: Springer, LLC.

Cummins, R. A. (1996). The domains of life satisfaction: An attempt to order chaos. Social Indicators Research, 38, 303-332. https://doi.org/10.1007/BF00292050

Cummins, R. A., Eckersley, R., Pallant, J., Van Vugt, J., \& Misajon, R. (2002). Developing a National Index of Subjective Wellbeing: The Australian Unity Wellbeing Index. Social Indicators Research, 64, 159-190. https://doi.org/10.1023/A:1024704320683

Day, R. L. (1987). Relationships between life satisfaction and consumer satisfaction'. In A. Coskun Samli (Ed.), Marketing and the quality of life interface. New York: Quorum Books.

Delhey, J. (2004). Life Satisfaction in an Enlarged Europe. Luxembourg: Office for Official Publications of the European Communities.

Diener, E. (1984). Subjective well-being. Psychological Bulletin, 95, 543-575. https://doi.org/10.1037/0033-2909.95.3.542

Diener, E., \& Diener, M. (1993). Cross-cultural correlates of life satisfaction and self-esteem. Journal of Personality and Social Psychology, 68(4), 653-666. https://doi.org/10.1037/0022-3514.68.4.653

Diener, E., Emmons, R. A., Larsen, R. J., \& Griffin, S. (1985) The Satisfaction with Life Scale. The Journal of Personality Assessment, 49(1), 71-72. https://doi.org/10.1207/s15327752jpa4901_13

Diener, E., Gohm, C. L., Suh, E., \& Oishi, S. (2000). Similarity of the relations between marital status and subjective well-being across cultures. Journal of Cross-Cultural Psychology, 31, 419-436. https://doi.org/10.1177/0022022100031004001

Diener, E., \& Seligman, M. E. P. (2004). Beyond money: Toward and economy of wellbeing. Psychological Science, 5, 1-31. https://doi.org/10.1111/j.0963-7214.2004.00501001.x

Dolan, P., Layard, R., \& Metcalfe, R. (2011). Measuring subjective well-being for public policy. Office for National Statistics.

Dolan, P., Peasgood, T., \& White, M. (2008), Do we really know what makes us happy? A review of the economic literature on the factors associated with subjective well-being, Journal of Economic Psychology, 29, 94-122. https://doi.org/10.1016/j.joep.2007.09.001

Dyrdal, G. M., Raysamb, E., Nes, R. B., \& Vitterso, J. (2011). Can a happy relationship predict a happy life? A population-based study of maternal well-being during the life transition of pregnancy, infancy and toddlerhood. Journal of Happiness Studies, 12, 947-962. https://doi.org/10.1007/s10902-010-9238-2

Efklides, A., Maria, K., \& Grace, C. (2003). Subjective quality of life in old age in Greece, 
the effect of demographic factors, emotional state, and adaptation to aging. Eur Psychol., 8, 178-191. https://doi.org/10.1027//1016-9040.8.3.178

Fadda, G., \& Jiron, P. (1999). Quality of life and gender: A methodology for urban research. Environment \& Urbanization, 11(2), 261-270. https://doi.org/10.1177/095624789901100220

Fernandez-Ballesteros, R., Zamarron, M. D., \& Ruiz, M. A. (2001). The contribution of socio-demographic and psychosocial factors to life satisfaction. Ageing and Society, 21(1), 25-43. https://doi.org/10.1017/S0144686X01008078

Ferring, F. D., Balducci, C., Burholt, V., Wenger, C., Thissen, F., Weber, G. et al. (2004). Life satisfaction of older people in six European countries: findings from the European study on adult well-being. Eur J Ageing, 1, 15-25. https://doi.org/10.1007/s10433-004-0011-4

Headey, B., \& Wearing, A. (1992). Understanding happiness: A theory of subjective well-being. Melbourne, Australia: Longman Cheshire.

Hlavac, M. (2011). Subjective life satisfaction in the European Union: Determinants and policy implications. https://doi.org/10.2139/ssrn.1853623

Ibem, E. O., \& Amole, D. (2013). Subjective life satisfaction in public housing in urban areas of Ogun State, Nigeria. Cities, 35, 51-61. https://doi.org/10.1016/j.cities.2013.06.004

Ibrahim, M. F., \& Chung, S. W. (2003). Quality of life of residents living near industrial estates in Singapore. Social Indicators Research, 61(2), 203-225. https://doi.org/10.1023/A:1021305620042

John, R. K. (1993). Activity and Aging: Staying Involved in Later Life. Newbury Park, CA: Sage.

Jovanović, V., \& Joshanloo, M. (2019). The determinants of life satisfaction in Serbia: Findings from the Gallup World Poll. International Journal of Wellbeing, 9(1), 43-60. https://doi.org/10.5502/ijw.v9i1.751

Keyes, C. L. M., Shmotkin, D., \& Ryff, C. (2002). Optimizing well-being: the empirical encounter of two traditions. $J$ Pers Soc Psychol., 82, 1007-1022. https://doi.org/10.1037/0022-3514.82.6.1007

Khanna, S. (2015). Organizational Role Stress (ORS) and Life Satisfaction among Female Doctors. Proceedings from International Conference of Technology and Business Management.

Kousha, M., \& Moheen, N. (2004). Predictors of Life Satisfaction among Urban Iranian Women: An Exploratory Analysis. Journal of Social Indicators Research, 40(3), 320-357.

Krause, N. (1993). Race differences in life satisfaction among aged men and women. Journal of Gerontology: Social Sciences, 48, S235-S244. https://doi.org/10.1093/geronj/48.5.S235

Maddox, G. L. (Ed.). (1987). The encyclopedia of aging: A Comprehensive Resource in Gerontology. New York: Springer 
Mannell and Dupuis. (1996). Life satisfaction (pp. 59-64). Encyclopedia of gerontology.

McAdams, K. K., Lucas, R. E., \& Donnellan, M. B. (2012). The role of domain satisfaction in explaining the paradoxical association between life satisfaction and age. Social Indicators Research, 109(2), 295-303. https://doi.org/10.1007/s11205-011-9903-9

McNeil, R. D., Teague, M. L., McGuire, F. A., \& O’Leary, J. T. (1987). Older Americans: A Literature Synthesis. Therapeutic Recreation Journal, 21, 18-25.

Melin, R., Fugl-Meyer, K. S., \& Fugl-Meyer, A. R. (2003). Life Satisfaction in 18- to 64-Year-Old Swedes: In Relation to Education, Employment Situation, Health and Physical Activity. Journal of Rehabilitation Medicine, 35(2), 84-90. https://doi.org/10.1080/16501970306119

Muzamil, J., \& Tasia, M. (2008) An Assessment of Life Satisfaction among Women. Studies on Home and Community Science, 2(1), 33-42. https://doi.org/10.1080/09737189.2008.11885250

National Bureau of Statistics (NBS) and United Nations Children's Fund (UNICEF). (2017). Multiple Indicator Cluster Survey 2016-17, Survey Findings Report. Abuja, Nigeria: National Bureau of Statistics and United Nations Children's Fund.

Neal, J. D., Sirgy, M. J., \& Uysal, M. (1999). The role of satisfaction with leisure travel-tourism services and experience in satisfaction with leisure life and overall life. Journal of Business Research, 44(3), 153-164. https://doi.org/10.1016/S0148-2963(97)00197-5

Neugarten, B. L., Havighurst, R. J., \& Tobin, S. S. (1961). The measurement of life satisfaction. Journal of Gerontology, 16, 134-143. https://doi.org/10.1093/geronj/16.2.134

OECD. (2013). OECD Guidelines on Measuring Subjective Well-being. OECD Publishing. https://doi.org/10.1787/9789264191655-en

Ozmete, E. (2011). Subjective well-being: A research on life satisfaction as cognitive component of subjective well-being. International Journal of Academic Research, 3(4), 5561.

Park, H. (2006). Housing welfare indicators for the quality of life in Korea. Housing Studies Review, 14(1), 5-26.

Pavot, W., \& Diener, E. (1993). Review of the satisfaction with life scale. Psychological Assessment, 5, 164-172. https://doi.org/10.1037/1040-3590.5.2.164

Pavot, W., \& Diener, E. (2008). The satisfaction with life scale and the emerging construct of life satisfaction. The Journal of Positive Psychology, 3(2), 137-152. https://doi.org/10.1080/17439760701756946

Penning, M. J., \& Strain, L. A. (1994). Gender Differences in Disability, Assistance, and Subjective Well-being in Later Life. Journal of Gerontology, 49(4), S202-S208. https://doi.org/10.1093/geronj/49.4.S202 


\section{MInstitute Macrothink $_{\text {Int }}$}

International Journal of Social Science Research

ISSN 2327-5510

2020, Vol. 8, No. 2

Peterson, C., Park, N., \& Seligman, M. E. P. (2005). Orientations to happiness and life satisfaction: The full life versus the empty life. Journal of Happiness Studies, 6, 25-41. https://doi.org/10.1007/s10902-004-1278-z

Ra, J., An, S., \& Rhee, K. J. (2013). The Relationship between Psychosocial Effects and Life Satisfaction of the Korean Elderly: Moderating and Mediating Effects of Leisure Activity. $J A H, 2(11), 21-35$.

Rice, R. W., Frone, M. R., \& McFarlin, D. B. (1992). Work-nonwork conflict and the perceived quality of life. Journal of Organizational Behavior, 13(2), 155-168. https://doi.org/10.1002/job.4030130205

Rode, J. C. (2002). The role of core evaluations within a comprehensive job and life satisfaction model: A longitudinal analysis. Dissertation Abstracts International (Section A: Humanities and Social Sciences), 63(5-A)

Ronald, I. (1997). Modernization and Post-modernization: Cultural, economic, and political change in 43 societies. Princeton university press.

Sacks, W. D., Stevenson, B., \& Wolfers, J. (2010). Subjective Wellbeing, Income, Economic Development and Growth. NBER Working Paper, (16441). https://doi.org/10.3386/w16441

Saundra, H. S., \& Hughey, A. W. (2003). African American Women at Mid-life: The Relationship between Spirituality and life Satisfaction. Journal of African American Women, 18(2), 133-147. https://doi.org/10.1177/0886109903018002004

Sirgy, M. J., \& Cornwell, T. (2001). Further validation of the Sirgy et al.'s Measure of Community Quality of Life. Social Indicators Research, 56(2), 125-143. https://doi.org/10.1023/A:1012254826324

Sirgy, M. J., Mentzer, J., Rahtz, D., \& Meadow, H. L. (1991). Satisfaction with Health Care Services Consumption and Life Satisfaction among the Elderly. Journal of Macro-Marketing, 11(1), 24-39. https://doi.org/10.1177/027614679101100103

Sirgy, M. J., Rahtz, D., Cicic, M., \& Underwood, M. (2000). A method for assessing residents' satisfaction with community-based services: A quality-of-life perspective. Social Indicators Research, 49(3), 279-316. https://doi.org/10.1023/A:1006990718673

Steger, M. F., \& Kashdan, T. B. (2007). Stability and specificity of meaning in life and life satisfaction over one year. Journal of Happiness Studies, 8, 161-179. https://doi.org/10.1007/s10902-006-9011-8

Steptoe, A., Deaton, A., \& Stone, A. A. (2015). Subjective wellbeing, health, and ageing. The Lancet, 385(9968), 640-648. https://doi.org/10.1016/S0140-6736(13)61489-0

Subasi, F., \& Hayran, O. (2005). Evaluation of life satisfaction index of the elderly people living in nursing homes. Archives of Gerontology and Geriatrics, 41, 23-29. https://doi.org/10.1016/j.archger.2004.10.005

Suh, E., Diener, E., Oishi, S., \& Triandis (1998). The shifting basis of life satisfaction 
judgments across cultures: Emotions versus norms. Journal of Personality and Social Psychology, 74(2), 482-493. https://doi.org/10.1037/0022-3514.74.2.482

Thieme, P., \& Dittrich, D. A. V. (2015). A life-span perspective on life satisfaction. SOEP papers on Multidisciplinary Panel Data Research, No. 775, Deutsches Institut für Wirtschaftsforschung (DIW), Berlin. https://doi.org/10.2139/ssrn.2612397

Tucker, K. L., Ozer, D. J., Lyubomirsky, S., \& Boehm, J. K. (2006). Testing for measurement invariance in the satisfaction with life scale: A comparison of Russians and North Americans. Social Indicators Research, 78, 341-360. https://doi.org/10.1007/s11205-005-1037-5

Van Praag, B., Frijters, P., \& Ferreri, C. A. (2003). The anatomy of subjective well-being. Journal of Economic Behavior \& Organization, 51, 29-49. https://doi.org/10.1016/S0167-2681(02)00140-3

Van Praag, B. M. S., \& Ferrer-i-Carbonell, A. (2004). Happiness quantified: A satisfaction calculus approach. Oxford: Oxford University Press. https://doi.org/10.1093/0198286546.001.0001

Veenhoven, R. (1996). Developments in satisfaction research. Social Indicators Research, 37, 1-46. https://doi.org/10.1007/BF00300268

Wright, T. A., \& Staw, B. M. (1999). Affect and Favourable Work Outcomes: Two Longitudinal Tests of the Happy-Productive Worker Thesis. Journal of Organizational Behavior, 20(1). https://doi.org/10.1002/(SICI)1099-1379(199901)20:1<1::AID-JOB885>3.0.CO;2-W

Yuan, L. L. (2001). Quality of life case studies for university teaching in sustainable development. International Journal of Sustainability in Higher Education, 2(2), 127-138. https://doi.org/10.1108/14676370110388345

\section{Copyrights}

Copyright for this article is retained by the author(s), with first publication rights granted to the journal.

This is an open-access article distributed under the terms and conditions of the Creative Commons Attribution license (http://creativecommons.org/licenses/by/4.0/). 